\title{
18. A különleges jogrendi esetkörök szabályozása Litvániában
}

SZENTPÁLI-GAVALLÉR PÁL

\section{A különleges jogrend alkotmányos és törvényi szintû́ szabályozása, esetkörei}

A különleges jogrend alkotmányos és törvényi szintû szabályozása tekintetében Litvániában az alkotmány ${ }^{1}$ a különleges jogrendi időszaknak és helyzeteknek kettő változatát, a hadiállapotot (karo padèties)² és a szükségállapotot (nepaprastoji padètis) ${ }^{3}$ ismeri.

Az első tényállás a hadiállapot, amelyet elsősorban a parlament jogosult bevezetni, azonban e vonatkozásban szerepet kaphat a Litván Köztársaság elnöke is. Ha az állam szuverenitását vagy területi integritását veszélyeztető fegyveres, illetve katonai támadás áll fenn, meghozza a szükséges intézkedéseket, amely határozatait a parlament utóbb jóváhagyhatja vagy hatályon kívül helyezheti. Ugyanígy kap a parlament vagy a köztársasági elnök egyfajta rendkívüli szerepkört, ha általános választás esedékes háborús időben, mert dönthetnek

1 Alkotmány (Lietuvos Respublikos Konstitucija).

2 Hivatalos angol fordításban: martial law.

3 Hivatalos angol fordításban: state of emergency.

Dr. Szentpáli-Gavallér Pál

pal.szentpali-gavaller@mfi.gov.hu

kutató (Mádl Ferenc Összehasonlító Jogi Intézet)

PhD-hallgató (Miskolci Egyetem, Deák Ferenc Állam- és Jogtudományi Doktori Iskola)

Szentpáli-Gavallér, P. (2021) 'A különleges jogrendi esetkörök szabályozása Litvániában' in Nagy, Z., Horváth, A. (szerk.) A különleges jogrend és nemzeti szabályozási modelljei, 398-413. o. Budapest: Mádl Ferenc Összehasonlító Jogi Intézet.

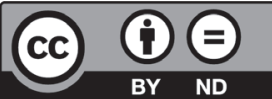

https://doi.org/10.47079/2021.nzha.kulon.4_18 
a mandátumok meghosszabbításáról. ${ }^{4}$ Általános jelleggel a végrehajtó hatalom általános szerve intézi az ország ügyeit, védi a Litván Köztársaság területének sérthetetlenségét. ${ }^{5}$

A litván szabályozásban a második tényállás a szükségállapot. Ez utóbbi elrendelésére is a parlament jogosult, azonban csak hat hónapot meg nem haladó időre. Ebben az esetben is fennáll a rendkívüli szerepköre a köztársasági elnöknek, ha a parlament nem ülésezik, ekkor ő maga dönt, egyidejúleg összehívja a parlament rendkívüli ülését a kérdés megvitatására. ${ }^{6}$ A szabályozás szerint a kormány az intézkedések megtételére általánosan felhatalmazott szerv, amely biztosítja az állam biztonságos múködését és a közrendet.7

Az előzőekben tárgyalt különleges jogrendi esetkörök, azaz a hadiállapot és a szükségállapot részletes szabályait Litvániában törvény állapítja meg. ${ }^{8}$ Ilyen különleges jogrendi állapotok idején alkotmánymódosításra nem kerülhet sor. ${ }^{9}$

A litván szabályozásban a különleges jogrendnek minősülő rendkívüli felhatalmazás esetköreit, alkotmányos és törvényi szabályozását ${ }^{10}$ érintően a hadiállapot részletszabályait ${ }^{11}$ lefektető törvény, valamint a szükségállapot részletszabályait ${ }^{12}$ megállapító törvény minősül a legfontosabb jogszabálynak. Ugyanakkor ezek a törvények közvetlenül kapcsolódnak a különleges jogrendhez is. Ezek a törvények szabályozzák e helyzetek meghatározását, a bevezetés feltételeit, a kihirdetés eljárásrendjét, valamint a kezelés szervezeti rendjét. ${ }^{13}$

További igen lényeges szabályozási forrás e területen a nemzetbiztonsági törvény, ${ }^{14}$ amely rendezi az állam területi épségének védelmét. Kiemelkedően fontos a civil lakosság felkészültségére, tájékoztatására vonatkozó rész, a felkészülés, valamint a civil lakosságnak a védelem és reagálás megszervezésébe való aktív bevonása. ${ }^{15}$

A polgári védelmi jogszabály ${ }^{16}$ fekteti le a jogi és szervezeti hátterét a polgári védelem litván rendszerének (erről részletesebben lásd az egészségügyi vészhelyzet kezeléséről szóló alfejezetet), így a hatáskörök részletszabályait, egyéb érintettek jogait és kötelezettségeit. Kiemelkedő tehát a jelentősége ennek a jogszabálynak a vészhelyzeti esemény (ivvykis) meghatározása okán, amely olyan természeti, technikai, ökológiai vagy társadalmi esemény, amely nem érte el a szükségállapot szintjét, mindemellett pedig veszélyezteti a lakosság életét vagy egészségét, társadalmi viszonyait, vagyonát, illetve környezetét. Míg a szükségállapot ehhez

\footnotetext{
4 Alkotmány 142 . cikk.

5 Alkotmány 94. cikk.

6 Alkotmány 144. cikk.

7 Alkotmány 94. cikk.

8 Alkotmány 144. cikk.

9 Alkotmány 147. cikk.

10 Elérhető: https://erccportal.jrc.ec.europa.eu/vademecum/lt/2-lt-1.html (Letöltve: 2019. december 14.).

11 A hadiállapotról szóló törvény (Lietuvos Respublikos karo padėties įstatymas).

12 A szükségállapotról szóló törvény (Lietuvos Respublikos nepaprastosios padėties įstatymas).

13 Survila et al., 2016.

14 A nemzetbiztonságról szóló törvény (Lietuvos Respublikos nacionalinio saugumo pagrindų įstatymas).

15 Survila et al., 2016, 40. o.

16 Polgári védelmi törvény (Lietuvos Respublikos civilinės saugos įstatymas) (a továbbiakban: Polgári védelmi tv.).
} 
képest olyan helyzet, amely vészhelyzeti esemény által jön létre, és hirtelen és súlyos veszélyt jelent a lakosság életére vagy egészségére, tulajdonukra, a környezetre, vagy halált, maradandó károsodást okoz, illetve fennáll annak a valószínűsége, hogy egyéb kárral jár együtt. E keretek között meghatározó a polgári védelem az állami, önkormányzati és egyéb szervek, gazdasági szereplők, valamint a lakosság felkészültsége vonatkozásában. Ki kell emelni a nemzetbiztonsági stratégiát $t^{17}$ is, amely a közpolitikai prioritások kijelölése kapcsán kap lényeges szerepet. Az állam egészét érintő vészhelyzetek elkerülése és következményeik mérséklése miatt Litvánia számára kiemelt fontosságú a lakossági képzés, a társadalmi minimumellátások biztosítása, végül pedig a polgári védelmi rendszer képességeinek és készségeinek növelése.

A különleges jogrend kihirdetésének gyakorlati esetei vonatkozásában említésre méltóak az utóbbi években azon esetek, amelyek élelmiszer-egészségügyi és időjárási okokkal voltak összefüggésben. Az afrikai sertéspestis terjedése miatt az országban szükségállapotot hirdettek ki, ${ }^{18}$ akárcsak 2018 során a nagymértékú szárazság miatt. ${ }^{19}$ Alkotmányjogi értelemben a viták nem is a különleges jogrendi időszaknak vagy helyzeteknek az alkotmányi szabályozásával, hanem a részletszabályok lefektetésével voltak kapcsolatosak. A hadiállapot részletszabályai esetében 2000-ig nem is fogadták el a kapcsolódó törvényt, azt követően is többször módosították, főlleg azt illetően, hogy az egyes felhatalmazottak és érintettek között milyen legyen az együttmúködés rendje. ${ }^{20}$

A leglényegesebb közjogi viták az utóbbi időben nem a konkrét szabályozás tárgyköréhez kötődtek, hanem hogy a hibrid hadviselés korában miként lehet értékelni egy kiprovokált konfliktust adott esetben a helyi (orosz ajkú) kisebbség körében történő nyugtalanság szításával - tekintettel a 2014-es ukrán eseményekre. Mennyiben lehetséges ilyenkor a NATO-szövetségi rendelkezések alkalmazása? Egyáltalán a hibrid hadviselés ilyen formáival szemben mi lenne a helyes védekezési mód?²1 Egyértelmú a balti államok lépése ebben a tekintetben, így igyekeznek kihasználni az összevont védelmi rendszerek kiépítéséből fakadó előnyöket, illetve illeszkedni az Európai Unió által nyújtott keretekhez. A három balti állam saját védelmi rendszerét magas szinten összehangolja a tengerészeti BALTRON ${ }^{22}$ és a légi megfigyelési BALTNET ${ }^{23}$ projektekben. A BALTRON-t 1998-ban alapították, és a tenge-

17 A Litván Köztársaság parlamentjének 2002. május 28-i IX-907. számú határozata a 2002. évi nemzetbiztonsági stratégia jóváhagyásáról (Lietuvos Respublikos Seimas nutarimas dèl nacionalinio saugumo strategijos patvirtinimo $2002 \mathrm{~m}$. gegužès $28 \mathrm{~d}$. Nr. IX-907).

18 Elérhető: https://ithuaniatribune.com/state-of-emergency-declared-in-north-east-lithuania-over-africanswine-fever/amp/ (Letöltve: 2019. december 13.).

19 Elérhetô: www.lrt.lt/en/news-in-english/19/1075163/lithuania-declares-state-of-emergency-over-drought?fb clid=IwARoD3PltFEQOuQ9LmkdL7zp21OA7VZoJ9kb5P55D17viBymhEoZERMpqwrU (Letöltve: 2019. december 13.).

20 Elérhetó: www.lrs.lt/sip/portal.show?p_r=10140\&p_k=2\&p_t=150608 (Letöltve: 2019 . december 11.).

21 Elérhetô: https://lithuaniatribune.com/how-long-could-lithuania-resist-open-military-aggression/ (Letöltve: 2019. december 10.).

22 Angolul: Navy squadron of the Baltics.

23 Angolul: Air defense and air space. 
részeti együttmúködés egyik legfontosabb projektje lett a térségben, hasonlóan a légi megfigyelés területén 1994-ben alapított BALTNET-hez. ${ }^{24} \mathrm{Az}$ EU és a NATO együttmúkködésével Finnországban létrejött a Hibrid Fenyegetések Elleni Központ, valamint a Kommunikációs Munkacsoport, hogy felvegye a küzdelmet az orosz hírportálok tevékenységével.

Meg kell említeni a 2007-es tallini bronzkatona (felszabadulási emlékmû) ügyét, ugyanis ekkor azt el kívánták távolítani az észt szervek, ami az orosz ajkú lakosság heves tiltakozását váltotta ki, valamint orosz szerverekről számtalan kibertámadás kísérte, az észt alapvető fontosságú ellátórendszereket és infrastruktúrát megtámadva. Az ezek után kiépített észt szerv meghatározó jelentőségủ lett a másik két balti állam számára is.

\section{Az alapjogok korlátozásával kapcsolatos kérdések}

A litván szabályozás esetében általános alapjog-korlátozási klauzulát nem alkalmaznak. Békeidőben az alapjog-korlátozási szabályok vonatkozásában az alkotmány és a kapcsolódó törvények ${ }^{25}$ betartása és betartatása jelenti Litvániában az alapjogok és szabadságjogok általános korlátját. Vaičaitis megállapítása ${ }^{26}$ szerint a litván jogtudományban és az ítélkezési gyakorlatban az alapjogoknak nincs koherens és meghatározott definíciója. Erre tekintettel és ettől függetlenül is elsődlegesen az alkotmány, valamint az alkotmánybíróság fellelhetô gyakorlata alapián szükséges vizsgálni Litvánia alapjogi szabályozását. Az alkotmánybírósági gyakorlat szerint az alapjog-korlátozás csak törvény alapján vagy törvényi szabályozás útján valósulhat meg, és csak az arányosság elve mentén, oly módon, hogy az alapjogok, valamint szabadságjogok lényege nem csorbulhat. A gyakorlatban például a tulajdonjoggal kapcsolatos korlátozás, azaz a kisajátítás törvényi szintû szabályozás alapján és megfelelő kártalanítás mellett történhet meg. ${ }^{27}$

Az állampolgárok szabad gyülekezési joga nem korlátozható. ${ }^{28}$ Ezt a jogot csak törvény korlátozhatja, és csak akkor, ha erre az állam vagy a társadalom biztonsága, a közrend, az emberek egészségének vagy erkölcsének, illetve más személyek jogainak vagy szabadságának megóvása érdekében van szükség. A litván szabályozás esetében általános alapjog-korlátozási klauzulát nem alkalmaznak.

Azon alapjogok tehát, amelyeket nem lehet korlátozni, vagy csak kivételesen, törvény alapján korlátozhatók: a véleménynyilvánítás joga, a lelkiismereti és vallásszabadság joga, a mozgásszabadsághoz való jog, valamint a gyülekezési jog. ${ }^{29} \mathrm{Az}$ alkotmány alapján korlátozhatatlan a kultu-

24 A BALTRON projektről lásd bővebben: www.mod.gov.lv/en/nozares-politika/international-and-regionalcooperation/regional-cooperation/navy-cooperation; a BALTNET projektről lásd bővebben az alábbi oldalt: www.mil.ee/en/defence-forces/international-co-operation/baltnet (Letöltve: 2019. december 10.).

25 Galginaitis, Himmelreich és Vrubliauskaité, 2010, 23-24. o.

26 Vaičaitis, 2020, 1078. 0.

27 Alkotmány 23. cikk (3) bekezdés.

28 Alkotmány 36. cikk (2) bekezdés.

29 Alkotmány 25. cikk (3) bekezdés, 26. cikk (1) bekezdés, 32. cikk (2) bekezdés, 36. cikk (2) bekezdés. 
rális, tudományos, kutatási és oktatási tevékenység. ${ }^{30} \mathrm{Az}$ előzőekkel összhangban az alkotmánybírósági gyakorlat rámutat, hogy az alapjog-korlátozás csak törvényi felhatalmazás alapján vagy törvényi szabályozás útján valósulhat meg, és csak az arányosság elve mentén oly módon, hogy az alapjogok, valamint szabadságjogok lényege nem csorbul. Ahogy arról már szó esett, az alkotmány a különleges jogrendi állapotnak két változatát ismeri: egyrészt a hadiállapotot, másrészt a szükségállapotot. A hadiállapot és szükségállapot kihirdetése esetén egyes ${ }^{31}$ jogok ideiglenesen korlátozhatók. ${ }^{32}$ Ilyen különleges jogrendi állapotok idején alkotmánymódosításra nem kerülhet sor. ${ }^{33} \mathrm{Ha}$ az általános választások háború idejére esnek, ${ }^{34}$ a parlament vagy az elnök dönti el, hogy meghosszabbítja-e a parlament, az elnök vagy az önkormányzatok hivatali idejét. Ilyen esetekben a választásokat a háború vége után három hónapon belül kell meghirdetni.

A Polgári védelmi tv. szabályozási területéhez kapcsolódó kormányhatározat ${ }^{35}$ mellékletét képező, az anyagi erőforrások biztosításának és az azokért fizetett kártalanítás eljárásrendjéről szóló dokumentum a következő együttmúködési kötelezettséget írja elő: olyan sürgős esetekben, amikor a lakosok életére, egészségére, vagyonára vagy környezetére vonatkozóan súlyos veszély merül fel, a rendelkezésre álló anyagi erőforrásokat a települési önkormányzat igazgatójának írásbeli kérésére szükség szerint átadják a mentési mûveletek parancsnokának vagy a gazdálkodó egységek és egyéb ügynökségek parancsnoka részére, akikkel e tárgykörben külön megállapodások még nem születtek. A tanulmány előző pontjához hasonlóan itt is ki kell emelni a területre vonatkozó meghatározó szabályok közül a nemzetbiztonsági stratégiát, amely a közpolitikai prioritások kijelölése kapcsán kap lényeges szerepet. Az állam egészét érintő vészhelyzetek elkerülése és következményeik mérséklése miatt Litvánia számára kiemelt fontosságú a lakossági képzés, a társadalmi minimumellátások biztosítása, valamint további cél a polgári védelmi rendszer szereplői képességeinek és készségeinek növelése. ${ }^{36}$ Idetartozik, hogy Litvániában a vonatkozó uniós irányelv átültetése $\mathrm{e}^{37}$ is elsősorban az információs rendszerek és az IT-kommunikációs rendszerek kapcsán lényeges szabályozást érintette. ${ }^{38}$

30 Alkotmány 42. cikk (1) bekezdés.

$31 \mathrm{Az}$ ideiglenesen korlátozható jogok közé tartozik a litván szabályozás szerint: a magánélet sérthetetlensége és a családi élet védelme, a levéltitok és egyéb közlések sérthetetlensége, a tulajdon sérthetetlensége, a véleménynyilvánítás szabadsága, a szabad mozgás és tartózkodás joga, valamint az egyesülési szabadság és a gyülekezési jog.

32 Alkotmány 145. cikk.

33 Alkotmány 147. cikk.

34 Khakee, 2009, 39. o.

35 A Litván Köztársaság kormányának 1107. számú határozata az anyagi erőforrások biztosításának és az állami ellátás megtérítésének, valamint a rendkívüli helyzetben felmerült károk miatti állami támogatás nyújtására vonatkozó eljárás jóváhagyásáról, 2010. július 21. (Dẻl materialinių išteklių teikimo ir kompensavimo už jų teikimą tvarkos aprašo ir valstybės paramos už žalą, patirtą dèl ekstremaliosios situacijos, teikimo tvarkos aprašo patvirtinimo $2010 \mathrm{~m}$. liepos $21 \mathrm{~d}$. Nr. 1107).

36 Polgári védelmi tv. 41.

37 Az Európai Parlament és a Tanács (EU) 2016/1148 irányelve (2016. július 6.) a hálózati és információs rendszerek biztonságának az egész Unióban egységesen magas szintjét biztosító intézkedésekről.

38 A nevezett irányelv átültetése miatt elfogadott új vagy módosított rendelkezések köre megtalálható az alábbi oldalon: https://eur-lex.europa.eu/legal-content/HU/NIM/?uri=CELEX:32016L1148\&qid=1576188128492 (Letöltve: 2019. december 6.). 


\section{A koronavírus-járvány és az egészségügyi vészhelyzet kezelése}

Ahogy azt már fentebb említettük, az alkotmányos szabályozásban ${ }^{39}$ foglaltakkal kapcsolatosan a közzétett szakirodalom megjegyzi, ${ }^{40}$ hogy a koronavírus-járvány idején bevezetett karantén megköveteli, hogy az azzal kapcsolatos korlátozásokat törvény írja elő, valamint elvárás az is, hogy a korlátozások megfeleljenek a szükségesség és az arányosság elvének, és törvényes célt kövessenek, amely cél a kérdéses jogtól függően változik.

A litván szabályozásban - a rendelkezésre álló információink szerint - nincsen egészségügyi vész- vagy válsághelyzetszerủ kategória önállóan szabályozva. A polgári védelmi törvényben ${ }^{41}$ található meg a korábban már említett veszélyhelyzet eseményének meghatározása. A polgári védelem területe az állami, önkormányzati és egyéb szervek, gazdasági szereplôk és a lakosság felkészültsége szempontjából kiemelten releváns. ${ }^{42}$ Ehhez a tárgykörhöz kapcsolódik az előző alfejezetben már részletezett és hivatkozott kormányhatározat. ${ }^{43} \mathrm{~A}$ Polgári védelmi tv. meghatározza a polgári védelmi-mentési rendszer megszervezésének és múködtetésének alapelveit, valamint az állami és önkormányzati intézmények, gazdasági társaságok, állami szervezetek és lakosok feladatait és jogait. ${ }^{44} \mathrm{~A}$ polgári védelmi rendszer céljai ${ }^{45}$ között kiemelt helyet foglal el az állami források optimális felhasználása, valamint a közbiztonság és a nemzetgazdaság múkködése. A célok és a feladatok végrehajtása érdekében a polgári védelmi intézményeknek a rendszer felépítésére és múködésére vonatkozó alapelvek mentén kell múködniük, ezenfelül a jogszabály meghatározza a polgári védelmi rendszer felépítésének és múködésének legfontosabb alapelveit ${ }^{46}$ is. A területi elv a polgári védelem nemzeti szintú szervezésére vonatkozik, amely magában foglalja az egész lakosságot, valamint a Litvánia területén tartózkodó külföldi állampolgárokat. A differenciálás elve szerint a polgári védelmi intézkedéseket és a mentési mûveletekre való felkészülést az egyes közigazgatási egységekben hajtják végre, figyelembe véve az állam területén várható veszély szintjét, valamint annak mértékét. A kényszeralkalmazás jogosultsága alatt értendő, hogy a polgári védelmi intézkedések kötelezőek

39 Alkotmány 145. cikk.

40 Dagilytè-Padskočimaite-Vainorienè, 2020.

41 Polgári védelmi tv. 5-6.

42 Polgári védelmi tv. 40.

43 A Litván Köztársaság kormányának 1107. számú határozata az anyagi erőforrások biztosításának és az állami ellátás megtérítésének, valamint a rendkívüli helyzetben felmerült károk miatti állami támogatás nyújtására vonatkozó eljárás jóváhagyásáról, 2010. július 21. (Dẻl materialinių išteklių teikimo ir kompensavimo už jų teikimą tvarkos aprašo ir valstybės paramos už žalą, patirtą dẻl ekstremaliosios situacijos, teikimo tvarkos aprašo patvirtinimo $2010 \mathrm{~m}$. liepos $21 \mathrm{~d}$. Nr. 1107).

44 Polgári védelmi tv. 1.

45 A polgári védelmi rendszer céljai: az állami források optimális felhasználásának garantálása, a közbiztonság biztosítása, a nemzetgazdaság működőképességének fenntartása, a vészhelyzetek lokalizálása és ezek hatásainak enyhítése, a nyilvánosság felkészítése vészhelyzet esetén a gyakorlati intézkedésekre és a polgári védelmi rendszerbe vetett bizalom erősítése.

46 A legfontosabb alapelvek: a területi differenciálás, a kényszer gyakorlásának jogosultsága, az átláthatóság, az állandó készenlét és az interoperabilitás. 
a közigazgatás és az önkormányzatok minden intézményére, minden gazdasági szervezetre és lakosra. Az átláthatóság elve a közigazgatás és az önkormányzati intézmények polgári védelem területén végzett tevékenységére vonatkozik, amelynek átláthatónak kell lennie a nyilvánosság és a tömegtájékoztatás szempontjából. A készenlét elve alapján a polgári védelmi rendszer intézményeinek és a haderônek folyamatos készenlétben kell lenniük a vészhelyzetben való intézkedés érdekében. Az interoperabilitás elve magában foglalja a polgári védelmi intézkedések és a vészhelyzetekben végrehajtott intézkedések hatékonyságát, amelyet biztosítani kell a közigazgatás és az önkormányzati intézmények, a polgári védelmi rendszer haderôi részére, azok interoperabilitási terveinek és irányítási rendszerének összehangolásával.

A polgári védelmi rendszer intézményeit az alkotmány, a parlament által elfogadott törvények és egyéb jogi aktusok, a köztársasági elnök döntései, a kormány határozatai, ${ }^{47}$ a miniszterelnöki rendeletek, a honvédelmi miniszter utasításai és a nemzetközi szerződések határozzák meg. Az államszervezet múködése szempontjából a különleges jogrend kihirdetése a kormány felelőssége, valamint ezen túlmenően a kormányzati felelősségi körbe tartoznak a különleges jogrend megszüntetésével ${ }^{48}$ kapcsolatos feladatok. A litván védelmi erôk és önkéntesek szükség esetén segítséget nyújthatnak válsághelyzetben. A korábbiakban már leírtakon túl a kormány felelősségi körébe tartoznak egyéb, lényegesnek nevezhetô tárgykörök ${ }^{49}$ is.

Békeidóben a honvédelmi minisztérium más intézményekkel együttmúködve végrehajtja a kormány polgári védelmi politikáját, valamint össze kell hangolnia a polgári védelmi rendszer intézményeinek tevékenységét a hatáskörükhöz rendelt feladatok végrehajtása során. A hivatalos kormányüléseken folytatott tevékenységen túl fontos szerepet kap a Stratégiai Bizottság, amelynek tagjai között szerepel a kabinetminiszteren és a kancelláron kívül egy miniszterelnök-helyettes. A Stratégiai Bizottság kezeli a kormány által meghatározott

47 Spassov-Petkov-Tagarev, 2016, 2. és 18. o. A válságkezelés területén a litván kormány alábbi határozatai meghatározók: az 551. számú, 2000. november 8-i határozat; az 512. számú, 2010. május 4-i határozat; az 555. számú, 2004. május 4-i határozat; a Litván Köztársaság polgári védelmi rendszerével kapcsolatos eljárásról szóló 2010. évi 1108. számú határozat; a mentési, kutatási és sürgősségi események, katasztrófák és vészhelyzetek felszámolására és következményeik felszámolására, valamint azok kiküszöbölésére vonatkozó 2010. évi 1212. számú határozat, a sürgősségi múveleti központok létrehozásáról és szervezéséről szóló 1213. számú határozat; a lakosság evakuálásáról szóló 2010. évi 1502. számú határozat, a 2010. évi állami vészhelyzetkezelési tervről szóló 1503. számú határozat.

48 A vészhelyzet megszüntetésével kapcsolatos feladatok a következők: a vészhelyzet megszüntetése; a mentési, kutatási és sürgős intézkedések megszervezése; a vészhelyzetekre való reagálás; a vészhelyzet következményeinek enyhítése; az evakuálási intézkedések, valamint a menedékhelyek és más kollektív védelmi mechanizmusok biztosítása.

49 Egyéb meghatározó kormányzati tárgykörök: a polgári védelmi rendszerek fejlesztési programjainak kidolgozása és a parlamenthez jóváhagyás céljából benyújtása; a polgári védelmi rendszerek prioritási fejlesztési trendjeinek végrehajtását szolgáló eljárás kidolgozása; a sürgősségi megelőzési eljárás kialakítása; a polgári védelem felkészültsége és a sürgősségi kritériumok jóváhagyása; a polgári védelmi vészhelyzeti felkészültség nemzeti szintû terveinek jóváhagyása; az anyagi erőforrások vészhelyzet esetén történő felhasználása, valamint az állami tartalék összetételének meghatározása; a polgári védelmi képzés; az elnök és a parlament a vészhelyzetről, annak következményeiről és okairól való értesítése. 
prioritásokat, valamint a kormányzati politikát és stratégiát. Egy másik kormánybizottság, a Válságkezelő Bizottság a válságkezeléssel kapcsolatban ad tanácsot a kormánynak..$^{50} \mathrm{~A}$ honvédelmi minisztérium ${ }^{51}$ felel továbbá:

- a Vészhelyzet-menedzsment Központ értesítési eljárásának meghatározásáért;

- a menedékhelyek és más kollektív védelmi struktúrák szükségleteinek biztosításáért;

- a lakosság egyéni védelmi eszközökkel történő ellátásával kapcsolatos normák jóváhagyásáért;

— a nemzeti szintû polgári védelmi gyakorlat és a hallgatók polgári védelmi képzési központba való beiratkozására vonatkozó éves terv jóváhagyásáért;

— a polgári védelmi osztály éves tevékenységi tervének jóváhagyásáért;

— valamint általános információkkal látja el a kormányt a polgári védelmi és mentési rendszer állapotáról.

Nemzeti szinten a kormányon belül a Vészhelyzet-menedzsment Központ mellett a Kormányzati Katasztrófavédelmi Bizottságközpont is segíti a kormányzati feladatok ellátását. ${ }^{52}$ A Belügyminisztérium Polgári Védelmi Osztálya a polgári védelmi rendszer nélkülözhetetlen része, amelynek főbb feladatai: ${ }^{53}$

— irányítja a polgári védelmi rendszer tevékenységeit, valamint a vészhelyzetek megelőzése érdekében folytatja a tevékenységét;

- összehangolja a közintézmények és az ökoszervezetek tevékenységét a polgári védelem területén; és

- előkészíti a polgári védelmi feladatok végrehajtásához szükséges nemzeti felkészültség tervét békebeli és háborús vészhelyzetek esetén.

Az Állami Túzoltóság és Mentőszolgálat is a polgári védelmi rendszer része, amely folyamatos készenlétben van, és intézkedik a tüzoltás, a sérültek felkutatása és mentése érdekében, valamint vészhelyzet esetén elsősegélyt nyújt. A mentőszolgálat a Belügyminisztérium Túzmegelőzési és Mentési Osztálya alárendeltségébe tartozik.

50 Nakrosis-Vilpisauskas-Jahn, 2016, 45. o.

51 Spassov-Petkov-Tagarev, 2016, 2. és 18. o.

52 Spassov-Petkov-Tagarev, 2016, 2. és 18. o.

53 A Polgári Védelmi Osztály előbb felsorolt főbb feladatain kívül - a polgári védelmi rendszer céljai között a polgári védelmi törvény által is elsők között meghatározott optimális forrásfelhasználáson túl - egyéb kötelezettségeket is teljesítenie kell, amelyek a következők: az állami intézmények, a gazdasági szereplők és a lakosság tájékoztatása vészhelyzet esetén az országos szintủ fenyegetettségről; az állami források optimális felhasználásának, a vészhelyzet térsége lokalizálásának és a válság következményeinek enyhítését célzó intézkedések megtervezése; a potenciálisan veszélyes nemzeti jelentôségú objektumok nyilvántartásának vezetése; a polgári védelmi rendszer tevékenységeinek ellenőrzése; a közigazgatási intézmények és a közösség vészhelyzetre való felkészültségének megszervezése; valamint a nemzeti szintủ polgári védelmi gyakorlat megszervezése és irányítása. 
Az előzőekben taglalt polgári védelmi rendszer fontosságát kiemeli az a tény is, hogy a Velencei Bizottság tavaly őszi jelentése is foglalkozik az új koronavírus litván szabályozásával. ${ }^{54} \mathrm{~A}$ jelentésben foglaltak szerint egyes országokban (például Ciprus, Görögország, Írország) vannak olyan mechanizmusok, amelyek a vészhelyzetekre reagálnak, mások (mint például Litvánia) pedig számos sürgősségi mechanizmussal rendelkeznek, amelyek megkülönböztetik a különböző típusú fenyegetéseket. Litvánia különleges sürgősségi intézkedéseket fogadott el a polgári védelemről szóló törvény, valamint az emberek fertőző betegségeinek megeloozésérôl és ellenőrzéséről szóló törvény, és nem az alkotmány ${ }^{55}$ alapján (tehát hivatalos formális szükségállapot kihirdetése nélkül).

Az új koronavírus-pandémiával kapcsolatos, ${ }^{56} 2020$ márciusában elrendelt korlátozásokat a három balti állam 2020. május 15-én egymás vonatkozásában feloldotta. Ezt követően, 2020. június 1-jén Litvánia több EU-tagállam - köztük Magyarország vonatkozásában is - a belépési tilalom megszüntetése iránt tett intézkedéseket.

A litván kormányzat a koronavírusra való tekintettel a következőkben bemutatott intézkedéseket ${ }^{57}$ rendelte el 2020. június 17-től: a határokon az ellenőrzés tekintetében - elsődlegesen korlátozó jellegû́ - szigorításokat léptettek életbe, ${ }^{58}$ a gazdaságban, tehát a szolgáltatásokat és a kereskedelmet érintően elsősorban - a hazai szabályozáshoz hasonlóan - a távolságtartást szolgáló intézkedéseket alkalmazták. ${ }^{59}$

54 Venice Commission, 2020, 14. o.

55 Alkotmány 144. cikk.

56 Elérhető: www.schengenvisainfo.com/news/timeline-of-eu-member-states-reopening-their-borders/ (Letöltve: 2020 . június 22.).

57 Lásd a litván kormányzati honlapot: http://koronastop.lrv.lt/en/news/Covid-19-related-restrictions-as-of-17june-2020 (Letöltve: 2020. július 24.).

58 A szigorítások között említésre méltók a következők: az érintett országokból Litvániába érkező rendszeres járatok és kompok korlátozása; az ellenőrzéseket a repülőtereken, a Klaipẻda tengeri kikötőben, valamint a Fehéroroszországgal és Oroszországgal folytatott külső uniós határátkelőhelyeken végzik (ez magában foglalja a testhőmérséklet mérését, elektronikus regisztrációval vagy papíralapú formanyomtatvány kitöltésével együtt az utaskártya kötelező kitöltése 48 órán belül, 14 napos elkülönítés ajánlott mindenkinek, adott esetben pedig betegállomány); az utasok tájékoztatása és konzultáció a további lépésekről, ha az utasoknál tünetek jelentkeznek; az utasok ellenőrzését az EU belső határain nem hajtják végre.

59 A szolgáltatásokat és a kereskedelmet érintő intézkedések esetében a következőket kell megemlíteni: kétméteres védőtávolság betartatása, amely válaszfalak alkalmazása vagy személyi védőfelszerelés viselése esetén kisebb lehet; a sorok közötti szükséges távolság legalább 1 méter; fertőtlenítés; bevásárlókocsik, illetve -kosarak fertőtlenítése az értékesítési pontokon, üzletekben; kézhigiénia (kézmosás, illetve kézfertőtlenítés); a tünetek megjelenése vagy elkülönítés esetén tilos a munkavégzés; javasolt, hogy mind a látogatók, mind a személyzet viseljen személyi védőfelszerelést. 
Az előzőekhez hasonlóan a szórakozóhelyek és vendéglátóhelyek ${ }^{60}$ esetében elsődlegesen a távolságtartásra és a higiéniára helyezték a hangsúlyt, valamint hasonló szabályozást alkalmaztak a kaszinók, játéktermek, szerencsejáték szervezésére szolgáló helyiségek tevékenységével kapcsolatban is.

A rendezvények vonatkozásában idősávonként lett szabályozva a nézők és a résztvevők száma, amelyet a következő táblázat szemléltet.

\begin{tabular}{|c|c|c|}
\hline Idősáv & $\begin{array}{c}\text { Kültéri rendezvények megen- } \\
\text { gedett maximális létszáma (fó) }\end{array}$ & $\begin{array}{c}\text { Beltéri (fedett térben) rendez- } \\
\text { vények megengedett maximális } \\
\text { létszáma (fó) }\end{array}$ \\
\hline $\begin{array}{c}\text { 2020. június 17-től } \\
\text { 2020. június 30-ig }\end{array}$ & 700 & 150 \\
\hline $\begin{array}{c}\text { 2020. július 1-jétől } \\
\text { 2020. július 16-ig }\end{array}$ & 1000 & 200 \\
\hline
\end{tabular}

\section{5. táblázat \\ A litván korlátozás változása 2020 nyarán \\ Forrás: a szerző saját szerkesztése}

A rendezvényekkel kapcsolatban megalkotott szabályok szerint javasolttá vált az egyéni védőeszközök viselése, fertőtlenítés, kézhigiénia (kézmosás, illetve -fertőtlenítés), a tünetek megjelenése vagy a személy karanténba kerülése esetén tilos a munkavégzés. Az oktatási tevékenység korlátlanul végezhető, ha a higiénia és a résztvevőknek a szükséges személyi védőeszközökkel történő ellátása biztosított, azonban ehhez további előírások is kapcsolódnak, úgy, mint az előző rendezvényekre vonatkozó hasonló szabályoknál: fertőtlenítés, kézhigiénia (kézmosás, illetve -fertőtlenítés), a tünetek megjelenése vagy az érintett személy elkülönítése esetén tilos a munkavégzés. Távoktatást kell alkalmazni, ha az előbbi feltételek nem teljesülnek.

A szociális szolgáltatások nyújtása esetén alkalmazandó szabályok szintén hasonló követelményrendszert ${ }^{61}$ tartalmaztak, mint a korábban már megismert intézmények sza-

60 Szórakozóhelyek esetében alkalmazott intézkedések: sorok között legalább egy méter; kötelező fertőtlenítés; kézhigiénia (mosás, illetve fertőtlenítés); a tünetek megjelenése vagy elkülönítés esetén tilos a munkavégzés; javasolt, hogy a személyzet személyi védőfelszerelést viseljen. A vendéglátóhelyek (éttermek, kávézók, bárok, éjszakai klubok és egyéb szórakozóhelyek) esetében bevezetett intézkedések: az asztalnál ülő személyek között kétméteres védőtávolság, amely lehet kisebb, ha válaszfalak vannak felszerelve; fertôtlenítés; kézhigiénia (kézmosás, illetve -fertőtlenítés); a tünetek megjelenése vagy elkülönítés esetén tilos a munkavégzés; ajánlott, hogy a személyzet személyi védőfelszerelést viseljen; az ételek bármilyen kiszerelése korlátlan (svédasztal, pult); a munkaidő sem korlátozott.

61 A szociális területet érintő követelményrendszer a következő: fertőtlenítés; kézhigiénia (kézmosás, illetve -fertôtlenítés); a tünetek megjelenése vagy elkülönítés esetén tilos a munkavégzés; ajánlott egyéni védőeszközök használata. 
bályozása. A szociális területhez képest az egészségügyi szolgáltatások terén - értelemszerúen - a szigorúbb előírások érvényesültek. ${ }^{62}$

2020. november 7.00:00 órától 2020. november 29. 24:00 óráig Litvánia ${ }^{63}$ karantént vezetett be az ország teljes területén. A litván kormányzati honlapon közzétett korlátozó intézkedések szerint tilos beltéri vagy kültéri, kereskedelmi vagy nem kereskedelmi jellegú, kulturális, szórakoztató, sportesemények, ünnepségek, vásárok, fesztiválok vagy más tömeges összejövetelek megtartása, ez alól kivételt képeznek egyrészt a zártkapus (nézők nélküli) nagy sportesemények, másrészt a temetések legfeljebb tíz fő részvételével.

Az előbbieken túl a kormányzat javasolta a magánszemélyeknek, hogy a lakóhely elhagyását csak a munka, a vásárlás, az egészségügyi és egyéb szolgáltatások körére korlátozzák. Továbbá javasolt a magánterületen tartott összejövetelek mellőzése vagy legfeljebb tíz olyan ember részvételével való megtartása, akik arcmaszkot viselnek, ezen túlmenően érdemes más családok, illetve háztartások tagjaival korlátozni a kapcsolattartást.

A vendéglátóhelyeket, a közétkeztetési létesítményeket, éttermeket, kávézókat, bárokat, éjszakai klubokat, más szórakozóhelyeket, kaszinókat, játéktermeket, bingótermeket bezárták, kivéve az ételt elvitelre árusító, természetes és jogi személyek által fenntartott üzleteket. A vendéglátásban dolgozó személyzet számára az ilyen vállalkozások, létesítmények területén védőmaszkok használata kötelező. Továbbá a védőmaszkok használata minden nyilvános helyen kötelező (mindenki számára hatéves kortól), e kötelezettség alóli kivételt képeznek: az egyéni edzések, olyan szolgáltatások nyújtása, amikor a szolgáltatás nem teljesíthetô, ha az ügyfél maszkot visel, továbbá azon fogyatékossággal élő személyek, akik egészségi állapotuk miatt nem viselhetnek maszkot. A közös helyiségekben arcmaszkot kötelező viselni. Nyilvános helyeken legfeljebb öt fő gyülekezhet, kivéve a családtagokat.

A tömegközlekedésen az utasok ülve utazhatnak, és legalább egy méter távolságot kell tartaniuk egymás között.

Az állami szektor vonatkozásában vegyes- vagy távmunka bevezetése vált szükségessé, kivéve, ha a feladatokat nem lehet távolról ellátni. E követelmény teljesítése a magánszektor számára is ajánlott.

Az üzletekben, szupermarketekben, piactereken és más nyilvános értékesítési helyeken, valamint azok környezetében látogatónként biztosítani kell a tíz négyzetméteres teret, vagy egyszerre csak egy látogatót lehet kiszolgálni.

A szálláshely-szolgáltatás esetén a teljesítendő követelmények közé tartozik, hogy legfeljebb két fő elhelyezése lehetséges egy szobában, kivéve a családtagokat, biztosítani kell,

62 E szigorúbb elöírások a következők: szolgáltatásmegújítási terv készítése; a betegforgalom kezelése az intézmény vezetője által megállapított eljárásrendnek megfelelően; a távszolgáltatások támogatása, lehetővé téve az egészségügyi szolgáltatások azon módszerének megválasztását, amely a legjobban megfelel a beteg elvárásainak; fokozott fertőzöttség-ellenőrzés; személyi védőeszközök biztosítása és használata; tesztelési stratégia alkalmazása.

63 Lásd Litvánia kormányzati honlapját: https://koronastop.lrv.lt (Letöltve: 2020. november 11.). 
hogy mindenki viseljen arcmaszkot, és legalább kétméteres távolság legyen a közös helyiségekben élő emberek között. A rekreációs, kulturális, szabadidős, szórakoztató szolgáltatásokat nyújtó vendéglátóegységek zárva tartanak.

Az óvodai és az általános iskolai nevelést és oktatást a múveleti parancsnok határozatában megszabott feltételeknek megfelelően kell biztosítani. A felnőttképzést és a szakképzést távoktatás keretében tartják meg.

$\mathrm{Az}$ egészségügyi intézményekben látogatási tilalmat rendeltek el, kivéve például a 14 évesnél fiatalabb gyermekek és a szülészeti osztályokon lévő betegek látogatását az adott intézmény vezetőjének engedélyével. A járóbeteg-szakellátás során a szolgáltatás érdekének legjobban megfelelő szolgáltatási módot kell alkalmazni, amely lehet előjegyzéses vagy telefonos konzultáció. A nemzeti sürgősségi múveletek állami parancsnoka dönt az egészségügyi intézmények tevékenységi koordinátorának kinevezéséről a Covid-19-szolgáltatások nyújtásának koordinálása érdekében. A koordinátor a polgármesterekkel és a helyi vezetőkkel együttmúködve szervezi a Covid-19-járvánnyal kapcsolatos szolgáltatások nyújtását. A koordinátor utasításai mind a szervező egészségügyi intézmények, mind a mozgósított egészségügyi intézmények számára kötelezők, hacsak jogszabály eltérően nem rendelkezik.

A korlátozó intézkedések hatályát 2020. november 25. napján a litván kormányzat 2020. december 17. napjáig meghosszabbította. ${ }^{64}$

\section{4. Összegzés}

Ahogy arról már szó esett, a különleges jogrend litván és a hazai hatályos szabályozása közötti lényegi eltérés az, hogy míg az előbbi két szabályozási tárgykört (hadiállapot és szükségállapot), addig az utóbbi, Alaptörvényben foglalt magyar szabályozás hat tényállást (rendkívüli állapot, szükségállapot, veszélyhelyzet, váratlan támadás, megelőző védelmi helyzet, terrorveszélyhelyzet) állapít meg.

A litván szabályozáshoz hasonlóan, a magyar szabályozás szerint az Országgyưlés hadiállapot kinyilvánítása vagy idegen hatalom fegyveres támadásának közvetlen veszélye (háborús veszély) esetén kihirdeti a rendkívüli állapotot, viszont a vizsgált ország szabályozásától eltérően az Alaptörvényünk szerint Honvédelmi Tanács létrehozására is sor kerül. Ahogy arról már az előzőekben is szó volt, a magyar szabályozás szerint a rendkívüli állapot idején a Honvédelmi Tanács gyakorolja a parlament által rá átruházott jogokat a köztársasági elnök jogai mellett, ehhez társulnak még a Kormány jogai. A Honvédelmi Tanács rendeletet alkothat, amely a rendkívüli állapot megszúnésével hatályát veszti, kivéve, ha az Országgyúlés a rendelet hatályát meghosszabbítja.

64 Litvánia kormányzati honlapja elérhető: https://koronastop.lrv.lt/lt/naujienos/su-Covid-19-susije-ribojimaiinformacija-atnaujinta-2020-m-lapkricio-25-d (Letöltve: 2020. december 2.). 
Szükségállapot idején az Országgyưlés akadályoztatása esetén a köztársasági elnök dönt a Magyar Honvédség felhasználásáról. Ebben az időszakban a rendkívüli intézkedéseket rendeleti úton a köztársasági elnök vezeti be. A rendeleti úton bevezetett rendkívüli intézkedések harminc napig maradnak hatályban, kivéve, ha hatályukat az Országgyúlés - akadályoztatása esetén a honvédelmi ügyekkel foglalkozó bizottsága - meghosszabbítja. A köztársasági elnök rendelete a szükségállapot megszúnésével hatályát veszti.

A litván szabályozással párhuzamosan az Alaptörvényünk szerint a törvényes rend megdöntésére vagy a hatalom kizárólagos megszerzésére irányuló fegyveres cselekmények, továbbá az élet- és vagyonbiztonságot tömeges méretekben veszélyeztető, fegyveresen vagy felfegyverkezve elkövetett súlyos, erőszakos cselekmények esetén szükségállapot kihirdetésére kerül sor. A hatályos magyar szabályozás szerint a különleges jogrend kihirdetéséhez az országgyưlési képviselők kétharmadának szavazata szükséges, ez eltérést jelent a litván szabályozáshoz képest, mert utóbbiban ilyen szavazati arány (azaz küszöb) nincs meghatározva. A két szabályozás közötti érdemi eltérést tehát az jelenti, hogy a magyar jogalkotás során cizelláltabb szabályozásra törekedtek. Egyúttal érdemes arra is felhívni a figyelmet, hogy a litván szabályozás általánosabb megfogalmazása szélesebb kereteket biztosít a rugalmasabb jogalkalmazásra, azonban ugyanezt más szempontból nézve - a magyar szabályozáshoz képest a litván jog nem alkalmaz minden tekintetben egyértelmú megfogalmazást, így megnyitja a többértelmúség, adott esetben az ezzel együtt járó jogbiztonság csökkenése előtti „utat”.

A litván szabályozás lényegének bemutatását szolgálja a következő táblázat.

\begin{tabular}{|c|c|c|}
\hline & Hadiállapot & Szülkségállapot \\
\hline Szabályozás szintje & \multicolumn{2}{|c|}{ Alkotmányos és törvényi szint } \\
\hline Elrendelési okok & $\begin{array}{l}\text { Az állam szuverenitását vagy te- } \\
\text { rületi integritását veszélyeztető: } \\
\text { — fegyveres támadás, } \\
\text { — katonai támadás. }\end{array}$ & $\begin{array}{l}\text { Az állam területén } \\
\text { bekövetkezett: } \\
\text { — vészhelyzet vagy } \\
\text { — válság. }\end{array}$ \\
\hline Elrendelés & \multicolumn{2}{|c|}{$\begin{array}{l}\text { A parlament jogosult bevezetni a Litván Köztársaság elnökével } \\
\text { együttmüködve. }\end{array}$} \\
\hline Felhatalmazott & \multicolumn{2}{|c|}{ Parlament } \\
\hline Gyakorlati esetek & Nem rendelték el. & $\begin{array}{l}\text { Két alkalommal: } \\
\text { - 2014: afrikai sertéspestis } \\
\text { - 2018: szárazság. }\end{array}$ \\
\hline $\begin{array}{l}\text { Különleges jogrendnek nem } \\
\text { minősülő rendkívüli helyzet }\end{array}$ & \multicolumn{2}{|c|}{ Veszélyhelyzeti esemény } \\
\hline
\end{tabular}

16. táblázat

Különleges jogrendi esetkörök Litvániában

Forrás: a szerző saját összeállítása 
Magyarország Kormánya 2020. november elején az Országgyúlésnek benyújtotta a Magyarország Alaptörvényének kilencedik módosításáról szóló tervezetet, amelyet az Országgyưlés 2020. december 15. napján elfogadott, és a vonatkozó rendelkezések 2023-ban lépnek hatályba.$^{65}$ Ennek értelmében - a két litván jogintézményhez képest - az Alaptörvény a kilencedik módosítását követően már csak három különleges jogrendi tényállást fog szabályozni: a hadiállapotot, a szükségállapotot és a veszélyhelyzetet. E módosítással - külföldi példák nyomán - a jogalkotó átláthatóbbá ${ }^{66}$ kívánja tenni a korábbi hat helyett három esetkörre módosuló különleges jogrendi tényállások rendszerét, amely a fegyveres védelmi és biztonsági tevékenységekben érintett szervezetekre vonatkozó szabályokkal egy korszerúbb, a változó biztonsági környezethez jobban alkalmazkodó és az elmúlt évek válságkezeléseinek tapasztalataira építő, hatékony rendszer kialakítására törekszik. A módosítás a korszerűsítés és a rendszerszintû megújítás mellett számos ponton többletgaranciákat épít be a védelmi és biztonsági funkciók ellátásának szervezeti, múködési és szabályozási keretei vonatkozásában is. A különleges jogrend intézményrendszerében - a módosítás eredményeként a köztársasági elnök és a Honvédelmi Tanács nem kap szerepet, és ennek következményeként a Kormány szerepe megerősödik, amit jelez a különleges jogrendre vonatkozó közös szabályokban foglalt rendeletalkotási jogkör hangsúlyossá válása. A módosítás nyomán a jövőbeli magyar és a litván szabályozás a tényállások száma és átláthatósága tekintetében hasonló lesz. A 2023-ban hatályba lépő magyar szabályozás két tényállása (a hadiállapot és a szükségállapot) elnevezésében megegyezik a litván szabályozás két tényállásával, viszont egyértelmú eltérés a két szabályozás között az, hogy a magyar szabályozásban a Kormány kap meghatározó szerepet a rendeletalkotási jogkörének köszönhetően.

Litvániában a leglényegesebb közjogi viták az utóbbi években - ahogyan arra korábban már utaltunk - nem a konkrét szabályozás tárgyköréhez tartoztak, valamint a járványügyi vészhelyzet kihirdetéséhez kapcsolódtak, hanem hogy a hibrid hadviselés korában miként lehet értékelni egy kiprovokált konfliktust adott esetben a helyi (orosz ajkú) kisebbség körében történő nyugtalanság szításával, tekintettel a 2014-es ukrán eseményekre. Mennyiben lehetséges ilyenkor a NATO-szövetségi rendelkezések alkalmazása? Egyáltalán a hibrid hadviselés ilyen formáival szemben mi lenne a helyes védekezési mód? Egyértelmú a balti államok lépése ebben a tekintetben, így igyekeznek kihasználni az összevont védelmi rendszerek kiépítéséből fakadó előnyöket, illetve illeszkedni az Európai Unió által nyújtott keretekhez. A három balti állam saját védelmi rendszerét a korábban leírtak szerint magas szinten összehangolja a tengerészeti BALTRON és a légi megfigyelési BALTNET projektekben.

A magyar szabályozás számára példaértékủ lehet a litván szabályozásban, hogy igen nagy hangsúlyt fektetnek a civil lakosság bevonására a polgári védelem területén és az egyéb vészhelyzetek leküzdésének kezelésében. Bár ebben a tekintetben a magyar katasztrófavé-

65 T/13647. számú tervezet: www.Parlament.hu/irom41/13647/13647.pdf (Letöltve: 2020. december 15.). A módosítást a kézirat lezártakor még nem hirdették ki a Magyar Közlönyben.

66 Vö.: Till, 2017, 73-75. o. 
delmi szabályozás is elkezdett bizonyos lépéseket megtenni (önkéntesen segítséget nyújtó személyek, az önkéntesen közremúködő társadalmi és karitatív szervezetek részt vehetnek a katasztrófák elleni védekezéssel összefüggő feladatok ellátásában). ${ }^{67} \mathrm{~A}$ civil lakosság ilyen formában való mélyebb bevonása lehetôvé teszi a közös fellépés eredményességének növelését, az ezzel foglalkozó szervek társadalmi elfogadottságának növelését, a további együttmúködés elmélyítését.

Litvániában a célok és a feladatok végrehajtása érdekében a polgári védelmi intézményeknek a rendszer felépítésére és múködésére vonatkozó alapelvek mentén kell mưködniük, ezért a litván polgári védelmi intézmények alapelveinek (a területi elvnek, a differenciálás elvének, a kényszeralkalmazás jogosultságának, az átláthatóság elvének, a készenlét elvének, az interoperabilitás elvének) szerepe kiemelendő, ugyanis mint lehetséges minta tartható számon a magyar joggyakorlat szempontjából.

Kiemelkedően fontos lehet a - már folyamatban lévő - határon átnyúló együttmúködési lehetőségek feltérképezése és megerősítése Magyarország esetében is, ami a kapcsolódó szabályozási környezet ismeretét elengedhetetlenné teszi. Emellett pedig a többi állammal való összefogás és a közös kapacitás kialakítása, kiépítése, megerősítése nem pusztán az anyagi eszközök szintjén lényeges, hanem a közös fellépés nagyobb elrettentő - természeti csapások esetén elhárító, továbbá katasztrófavédelmi - erőt is képvisel, valamint további együttmúködési pontok kiépítésére ad lehetőséget. Ennek az összefogásnak első lépése lehetne a V4 együttmúkködési kereteinek - akár északi irányú - bővítése, hiszen a balti államok Lengyelország, és így a V4 közvetlen szomszédságában vannak. Az esetleges bővítés további indokaként tartható számon az a tény, hogy meghatározók (voltak) az elmúlt három évtized történelmi párhuzamai, valamint hasonlóan szignifikánsak a kulturális hasonlóságok, így ezek egyaránt megalapozzák egy esetleges bővítés lehetőségét.

\section{Irodalomjegyzék}

Aleknavičıus, P. (2013) 'Agrarian Land Use Regulation in the Republic of Lithuania', Balanced Nature Using, 2013/2-3, 18-26. o.

Dagilytė, E., Padskočimaité, A., VainorienĖ, A. (2020) Lithuania's Response to COVID-19: Quarantine Through the Prism of Human Rights and the Rule of Law [Online]. Elérhetô: https:// verfassungsblog.de/lithuanias-response-to-Covid-19-quarantine-through-the-prism-ofhuman-rights-and-the-rule-of-law/ (Letöltve: 2020. szeptember 15.)

Galginaitis, J., Himmelreich, A., Vrubliauskaité, R. (2010) Einführung in das litauische Recht. 1. kiadás. Berlin: BWV Berliner Wissenschafts-Verlag

67 A katasztrófavédelemről és a hozzá kapcsolódó egyes törvények módosításáról szóló 2011. évi CXXVIII. törvény, megállapította a 2013. évi CXCII. törvény 21. \$ (1) bekezdés, hatályos: 2013. 11. 29-től. 
Greicius, M. (2009) States of Emergency and Fundamental Rights: Lithuanian Perspective [Online]. Elérhetô: $\quad$ www.jus.unitn.it/cocoa/papers/PAPERS\%204TH\%20PDF/Emergency\%20Lithuania\%20Greicius.pdf (Letöltve: 2020. december 15.); www.sgi-network.org/docs/2016/ country/SGI2016_Lithuania.pdf (Letöltve: 2020. december 15.)

KELEMEN, R. (2020)'Különlegesjogrend az Európai Unióegyestagállamainakalkotmányaiban' in Farkas, Á., Kelemen, R. (szerk.) Szkülla és Kharübdisz között-Tanulmányok a különleges jogrend elméleti és pragmatikus kérdéseiról, valamint nemzetközi megoldásairól. 1. kiadás. Budapest: Magyar Katonai Jogi és Hadijogi Társaság

Khakee, A. (2009) Securing Democracy? A Comparative Analysis of Emergency Powers in Europe. Geneva Centre for the Democratic Control of Armed Forces. Policy Paper No. 30/2009

NAKRosis, V., VILPISAUSKAS, R., JAHN, D. (2016) Lithuania Report. Sustainable Governance Indicators 2016 [Online]. Elérhető: www.researchgate.net/publication/306380796_Lithuania_report_ Sustainable_governance_indicators_2016 (Letöltve: 2020. december 15.)

SADURSKI, W. (2005) Rights Before Courts: A Study of Constitutional Courts in Postcommunist States of Central and Eastern Europe. 1. kiadás. Dordrecht: Springer

Spassov, P., Petkov, V., Tagarev, T. (2016) Lithuania Policy, Legislation, Organisation, Procedures \& Capabilities (PLOPC) in Crisis Management and Disaster Response (Driving Innovation in Crisis Management for European Resilience) [Online]. Elérhető: www. driver-project.eu/wp-content/uploads/Crisis-Management-Organisations-Reportincluding-Procurement-Regulations-AND-Policy-and-Legislation-Report.pdf (Letöltve: 2020. december 11.)

Survila, A., RakšnYs, A. V., TVaronavičiené, A., Vainiutė, M. (2016) 'Systemic Changes in Disaster Management in the Context of Public Sector Modernization', Journal of Security and Sustainability Issues, 6(1), 37-52. o.

TILL, Sz. (2017) 'A különleges jogrendi kategóriarendszer egyszerủsítésének jövőbeli esélyei', Iustum Aequum Salutare, 13(4), 55-75. o.

VAIČAitis, A. V. (2020) 'Lithuania (Lithuanian Constitutional Law)' in Alen, A., Haljan, D. (szerk.) International Encyclopedia for Constitutional Law. Wolters Kluwer Online

Venice Commission (2020) Interim Reporton the Measures Taken in the EU Member States as a Result of the COVID-19 Crisis and Their Impacton Democracy, the Rule of Law and Fundamental Rights (Study No. 995/2020) [Online]. Elérhetô: www.venice.coe.int/webforms/documents/?pdf=CDL$\mathrm{AD}(2020) 018$-e (Letöltve: 2020. december 15.) 